\title{
The Effect of Ethanolic Extract of Acacia Seyal Bark on Induced Diabetic rats
}

\author{
Elamin Elhasan LM ${ }^{1}$, Basmat Elhkotam ${ }^{2}$, Tomader Salah Abdelgadir ${ }^{1}$, SMAHER GREEB ALLAH \\ IBRAHEIM $^{1}$, Omar Musa Izz Eldin Othman ${ }^{3}$.
}

\author{
Academic affiliations \\ 1. Omdurman Islamic University, Faculty of Science and Technology, Department of Biotechnology, \\ Khartoum. \\ 2. National Public Health Laboratory, Department of Molecular biology \\ 3. Professor - Biotechnology Department of Nutrition and Diabetics - Faculty of Biotechnology and \\ Health Science National Rebat University.
}

Corresponding author: Lina Mohamed Elamin Abdelmagid Elhasan, Department of Biotechnology, Omdurman Islamic University, Khartoum, Sudan. E-mail:lina2014371@gmail.com

\begin{abstract}
Background: Diabetes mellitus Type 2 is a chronic metabolic disorder characterized by insulin insensitivity that leads to a decrease in glucose transport into the other cells. Many drugs are being developed, while no cure is available regarding to this disease although, there are limitations due to high cost and certain side effects. The Traditional Medicines are preferred due to lesser side effects and low cost. Acacia species have wide traditional medicinal using as anti-diabetic, antimicrobial, and antiinflammatory activities.
\end{abstract}

Objective: The study aimed to examine the effect of ethanolic extract of Acacia Seyal bark in induced diabetic rats.

Materials and methods: Acacia Seyal bark was extracted in ethanol 80\%. The Ethanolic extract was analyzed for phytochemicals screening tests using standard methods. To investigate the effect of the extract thirty induced diabetic albino rats introduced by injection of glucose $2 \mathrm{~g} \backslash \mathrm{kg}$ were divided to 5 groups equally; Group 1 was treated with $10 \mathrm{mglkg}$ of glibenclamide, group 2 left as control treated with distilled water $10 \mathrm{mg} \backslash \mathrm{kg}$, Group 3 was treated with $200 \mathrm{mg}$ of plant extract, Group 4 was treated with $400 \mathrm{mg}$ of plant extract, and Group 5 was treated with $800 \mathrm{mg}$ of plant extract. The Glucose Tolerant Test were done after 1 hour, 2 hour and 4 hour to determine blood glucose level of rats. Estimation of in vitro glucose uptake by rat diaphragm experiment was done to evaluate the glucose utilization capacity of extract.

Results: The effect of different concentration of ethanolic extract of Acacia Seyal bark on the blood glucose level of diabetic induced rats is significantly different $(0.05 \mathrm{p} 0.01<\mathrm{p})$. The phytochemical screening of extract indicated the presence of Saponin, Tannins Steroids, Triterpens, and Anthraquinone, While the absence of flavonoids. In vitro glucose consumption by diaphragm study the level of utilized glucose from the media is $69.4 \%$ in the presence of extract compared to control group.

Conclusion: Study concluded that the ethanolic bark extract of A. seyal showed significant anti-diabetic activity. This results might have a great potential for translation to humans and the obtained data might set the stage for clinical trials investigating the effects of anti-diabetic effect in patients with diabetes mellitus type 2. In the best of our knowledge, this is the first study that has conducted to study the antidiabetics effect of ethanolic extract of Acacia Seyal bark in diabetic rats.

Key words: Acacia Seyal Bark, Diabetes mellitus type 2, Ethanolic extract, Anti diabetic activity, Phytochemical screening. Glucose Tolerance Test. 


\section{1- Introduction}

The incidence of Diabetes mellitus Type 2 (DM) has been increasing over the world, It is estimated that 439 million people would have type 2 DM by the year $2030^{[} \underline{1}, \underline{2}$.

Diabetes mellitus Type $2(\mathrm{DM})$ is a chronic metabolic disorder characterized by insulin insensitivity as a result of insulin resistance, declining insulin production, and eventual pancreatic beta-cell failure $[\underline{3}, \underline{4}$. that leads to a decrease in glucose transport into the liver, muscle cells, and other cells ${ }^{[} \underline{5}$. The pathophysiological changes of DM type 2 occur in several years before its detection. So early detection and treatment of disease can suppress disease's progression, complications, and prevent beta-cell dysfunction ${ }^{[} \underline{6}$. Early screening and diagnosis of DM type 2 are prevent of disease for $98 \%$, the result that a positive screen is equivalent to a diagnosis of pre-diabetes or $\left.\mathrm{DM}^{[} \underline{7}\right]$, Although about $25 \%$ of patients with type $2 \mathrm{DM}$ already have microvascular complications at the time of diagnosis suggesting that they have had the disease for more than 5 years $[\underline{8}]$. Type 2 DM can be prevented with lifestyle modification; exercise and diet control and community awareness about the disease. $\underline{2}^{[}$.

Many drugs are being developed, while no cure is available regarding to this disease $\left.{ }^{[}\right]$Although, there are limitations due to high cost and certain side effects such as development of hypoglycemia, weight gain, gastrointestinal disturbances, liver toxicity $\left.{ }_{[9}^{[}\right]$, efforts are on to find suitable anti-diabetic therapy.

The Traditional Medicines from medicinal plants which used by about $60 \%$ of the world's population, are preferred due to lesser side effects, availability, and low cost. A list of medicinal plants have anti-diabetic effects ${ }^{\left[10^{]}\right.}$. In example Acacia species have medicinal benefits as anti-diabetes $\underline{11}^{[} \underline{12}^{]}$and anti-microbial $\underline{13}, \underline{14}$.

Acacia seyal belongs to the family of Fabaceae (Mimosoideae). It is a small to mediumsized tree and up to $17 \mathrm{~m}$ tall and $60 \mathrm{~cm}$ in diameter, it is widespread in the semi-arid zone of tropical Africa and the Red Sea and from the Nile valley south to Zambia $\underline{12}$, $\underline{13}^{]}$. In Sudan, A. seyal, locally known as Talha $\underline{14}^{[}$, It is one of the most important medicinal plants used in traditional, or alternative, medicine ,fodder sources for livestock in Sudan $\underline{15}^{]}$, and source of gum Arabic. Gum Arabic (GA) is a mixture of polysaccharides and glycoproteins secreted from Acacia senegal, Acacia seyal, and 
Acacia nilotica trees' stems $\underline{16}^{[}$Pharmacologically, GA has been confirmed to have several therapeutic actions, such as being hypoglycemic, antidiabetic, antioxidant, immunomodulatory, antiulcer, protect against hepatic, renal, and cardiac complications in diabetic and chronic renal failure patients ${ }^{[17]}$.

\section{2- Materials and methods}

\section{2-1 Plant collection:}

The bark of Acacia Seyal was collected from Kordufan in western region of Sudan. The bark was washed under tap water and completely shade dried at room temperature. Then ground into fine powder by mortar and pestle. The powders were packed in clean plastic bag.

\section{2-2 Preparation of Ethanolic extract:}

Extraction was carried out according to method described by Sukhdev $\left.{ }^{[} \underline{18}\right] 100 \mathrm{~g}$ was coarsely powdered using mortar and pestle. Coarsely sample was extracted with ethanol $80 \%$ using Soxhlet extractor apparatus. Solvents were evaporated under reduced pressure using rotary evaporator apparatus. Finally extracts allowed to air in Petri dish till complete dryness.

\section{2-3 phytochemical screening tests}

Phytochemical screening for the active constituents was carried out on Methanolic extract using the methods described by (Martinez \& Valencia (1999), Sofowora (1993), Harborne (1984) and Wall et al (1952)) with many few modifications [19-22]

\section{2-3-1 Identification of tannins:}

$0.5 \mathrm{~g}$ of the extract washed three times with petroleum ether, dissolved in $10 \mathrm{ml}$ hot saline solution and divided in two tests tubes. To one tube 2-3 drops of ferric chloride added and to the other one $2-3$ drops of gelatin salts reagent added. The occurrence of a blackish blue colour in the first test tube and turbidity in the second one denotes the presence of tannins.

\section{2-3-2 Test of sterols and triterpenes:}

$0.5 \mathrm{~g}$ of the extract washed three times with petroleum ether and dissolved in 10 of chloroform. To $5 \mathrm{ml}$ of the solution, $0.5 \mathrm{ml}$ acetic anhydride was added and then 3 drops 
of conc. Sulphuric acid at the bottom of the test tube. At the contact zone of the two liquids a the gradual appearance of green, blue pink to purple color was taken as an evidence of the presence of sterols (green to blue) and or triterpenes (pink to purple) in the sample.

\section{2-3-3 Tests for Flavonoids: -}

$0.5 \mathrm{~g}$ of the extract was washed three times with petroleum ether, dissolved in $30 \mathrm{ml}$ of $80 \%$ ethanol. The filtrate was used for following tests: -

A/ to $3 \mathrm{ml}$ of the filtrate in a test tube $1 \mathrm{ml}$ of $1 \%$ potassium hydroxide solution in methanol was added. Appearance of a yellow color indicated the presence of Flavonoids. Flavones or and chalcone.

$\mathrm{B} /$ to $2 \mathrm{ml}$ of the filtrate $0.5 \mathrm{ml}$ of $10 \%$ lead acetate was added. Appearance of creamy turbidity was taken as an evidence of Flavonoids.

\section{2-3-4 Test for Saponins: -}

$0.3 \mathrm{~g}$ of the extract was placed in a clean test tube. $10 \mathrm{ml}$ of distilled water was added, the tube stoppered and vigorously shaken for about 30 seconds. The tube was then allowed to stand and observed for the formation of foam, which persisted for least an hour, was taken as evidence for presence of saponins.

\section{2-3-5 Test for Anthraquinone glycoside: -}

$0.5 \mathrm{~g}$ of the extract was boiled with $10 \mathrm{ml}$ of $0.5 \mathrm{~N} \mathrm{KOH}$ containing $1 \mathrm{ml}$ of $3 \%$ hydrogen peroxide solution. The mixture was extracted by shaking with $10 \mathrm{ml}$ of benzene. $5 \mathrm{ml}$ of the benzene solution was shacked with $3 \mathrm{ml}$ of $10 \%$ ammonium hydroxide solution and the two layers were allowed to separate. The presence of Anthraquinone was indicated if the alkaline layer was found to have assumed pink or red color.

\section{2-4 Laboratory animals}

Thirty albino mice (80-120g) were housed in polypropylene cages inside a wellventilated room at $20 \pm 4{ }^{\circ} \mathrm{C}$ and 12-h periods of light and dark, with free access to clean water and commercial mice food. All mice were fasted for $18 \mathrm{~h}$ before experimental induction of diabetes. At the end of experimental period, animals were sacrificed. 


\section{2-5 Induction of hyperglycemia}

Diabetes was induced experimentally by administration of $50 \%$ glucose. The animals were fasted for 18 hours, but allowed free access to water. A dose of $2 \mathrm{~g} / \mathrm{kg}$ body weight glucose was administered by intraperitoneal injection, blood glucose level was determined by use of colorimeter.

\section{2-6 Experimental design}

The rats were divided in to five groups, each group contain 6 rats. Group 1 was treated with $10 \mathrm{mg} \backslash \mathrm{kg}$ of glibenclamide, group 2 left as control treated with distilled water $10 \mathrm{mglkg}$. Group 3 was treated with $200 \mathrm{mg}$ of plant extract. Group 4 was treated with $400 \mathrm{mg}$ of plant extract. Group 5 was treated with $800 \mathrm{mg}$ of plant extract.

\section{2-7 Blood sampling}

Blood samples were collected from the rats using orbital techniques to determined blood glucose level. Blood samples were collected from the retro bulbar plexus of the median canthus of the eye of the rats. A micro capillary tube was carefully inserted into the medial canthus of the eye to puncture the retro bulbar plexus and thus enable out flow of about $2 \mathrm{ml}$ of blood into a blood glucose test tube. Then, test tubes were centrifuged at 3,000 rev per min using a table centrifuge. The Glucose Tolerance Test. was done at the start of the experiment and after 1,2 , and 4 hours $\underline{[23}]$.

\section{2-8 Estimation of in vitro glucose uptake by rat diaphragm}

Glucose uptake by rat diaphragm in vitro was estimated by a standard method. Two rats were weighing between 170 to $210 \mathrm{~g}$ were used in this study. The rats were anesthetized and dissected and cut into two equal halves. The diaphragms were dissected out quickly with minimal trauma and divided into 2 halves. The diaphragms were rinsed in cold tyrode solution Tyrode ( $\mathrm{NaCl}(8 \mathrm{gm} / \mathrm{L}), \mathrm{KCl}$ (0.20 gm/L), $\mathrm{CaCl} 2(0.20 \mathrm{gm} / \mathrm{L}), \mathrm{MgCl} 2$ (0.10 gm/L), NaH2PO4 (0.05 gm/L), NaHCO3 (1 gm/L), Glucose (1 gm/L) having pH 6.5) without glucose to remove any blood clots and were placed in small culture tubes containing $2 \mathrm{ml}$ tyrode solution. Four sets containing of incubating tubes were prepared as followed; Tube I which called PRO contained of $2 \mathrm{ml}$ of tyrode solution and $1 \mathrm{ml}$ of insulin $(0.25 \mathrm{IU} / \mathrm{ml})$, tube II which present the control contained of $2 \mathrm{ml}$ of tyrode solution, tube III contained of $2 \mathrm{ml}$ of tyrode solution and $1 \mathrm{ml}$ of extract, tube IV 
contained of $2 \mathrm{ml}$ of tyrode solution, $1 \mathrm{ml}$ of extract, and $1 \mathrm{ml}$ of Insulin. The volumes of all tubes were made up to $4 \mathrm{ml}$ with distilled water to match the volume of the tube

IV.

Each diaphragms were placed in incubating tubes and incubated for $30 \mathrm{~min}$ at $37^{\circ} \mathrm{C}$ in an atmosphere of $95 \%$ oxygen, and glucose $2 \%$ with shaking at 140 cycles $/ \mathrm{min}$. Glucose uptake per gram of tissue was calculated as the difference between the initial and final glucose content in the incubated medium.

\section{2-9 Data analysis}

Differences between the means of the various groups of in the efficacy study was done using ANOVA statistical test, while the differences between the means of the two groups used in the effect of different concentration of Acacia Seyal bark ethanolic extract were done using students t-test. Level of significance for all the analysis was set at $\mathrm{P}<0.05$.

\section{3- Results}

\section{3-1 Yield Percentage of Ethanolic Extraction of Acacia Seyal Bark:}

The yield percentage of Ethanolic Extraction of Acacia Seyal bark were calculated as followed: Weight of extract obtained / weight of plant sample X100, that shown in table I.

Table I: The Yield Percentage of Ethanol Extraction of Acacia Seyal bark

$\begin{array}{llll}\text { Sample } & \text { Weight of sample in } \mathrm{gm} & \text { Weight of extract } & \text { Yield \% } \\ \text { Acacia Seyal } & 50 \mathrm{~g} & 5.242 & 10.5 \%\end{array}$

\section{3-2 phytochemical screening test of Ethanolic Extract of Acacia Seyal bark:}

Qualitative screening of Ethanolic extract of Acacia seyal indicated the presence of sponin, tannins, steroids, triterpens and anthraquinone and the absence of flavonoide. That shown in table II.

Table II: Phytochemical screening test of Ethanolic extract of Acacia Seyal bark Sampl Saponin Flavonoids Tannins Steroids Triterpens Anthraquinone e 


$\begin{array}{lllllll}\begin{array}{l}\text { Acacia } \\ \text { seyal }\end{array} & ++ & - & ++ & ++ & ++ & ++ \\ \text { Key: + Trace, } & ++ \text { Moderate, } & +++ \text { High, } & & \text { - Negative }\end{array}$

3-3 The effect of different concentration of Ethanolic extract of Acacia Seyal bark

The blood glucose level of diabetic rats is significantly different $(0.05 \mathrm{p} 0.01<\mathrm{p})$ after 1 hour, 2 hours, and 4 hours from the initiation of the experiment was determine by Glucose Tolerant Test using calorimeter, that shown in table III

Table III: Effects of orally administered different concentration of Ethanolic extract of Acacia seyal in diabetic rats and the level of blood glucose, using t test

$\begin{array}{llll} & \mathbf{1 h r} & \mathbf{2 h r} & \mathbf{4 h r} \\ \text { Control/ } & 121.3 & 113.4 & 181.5 \\ \text { glibenclamide } & 132.3 & 140.3 & 139.7 \\ 200 \mathrm{mg} / \mathrm{kgbw} & 83.7 & 100.2 & 114 \\ 400 \mathrm{mg} / \mathrm{kgbw} & 85.7 & 96 & 123 \\ 800 \mathrm{mg} / \mathrm{kgbw} & 70 & 81.8 & 96.3 \\ \text { L.S.D } & 30.7 & 24.3 & 37.4\end{array}$

Previous results are expressed as Means \pm SD for five animals per group. Values followed by the same superscript are statistically different $(\mathrm{P} \leq 0.05$; Analysed by ANOVA test that shown in table IV.

Table IV: Table IV: The value of Means \pm SD of the effect of different concentration of Ethanolic extract of Acacia Seyal analyzed by ANOVA test

$\begin{array}{lclll}\begin{array}{l}\text { Source of } \\ \text { variation }\end{array} & \text { d.f } & \begin{array}{l}\text { Blood glucose } \\ \text { level after } \\ \text { hour }\end{array} & \begin{array}{l}\text { Blood glucose } \\ \text { level after } \\ \text { 2hour }\end{array} & \begin{array}{l}\text { Blood glucose } \\ \text { level after } \\ \text { 4hour }\end{array} \\ \begin{array}{l}\text { Acacia Seyal } \\ \text { Extract }\end{array} & 4 & \text { ns } 403.65 & \text { xx6983 } \\ \begin{array}{l}\text { Error } \\ \text { C.V }(\%)\end{array} & 25 & 987.156 & 417.288 & 183.4 \\ & & 31.77 & 19.2 & 10.6\end{array}$

$\mathrm{X}$ there is significant different at level of significant $5 \%$ $\mathrm{XX}$ there is significant different at level of significant $1 \%$ 
d.f $=$ degree of freedom

(\%) 207 co sufficient of variation

\section{3-4 Estimation of in vitro glucose uptake by rat diaphragm}

To estimate the Glucose uptake per gram of tissue was calculated as the difference between the initial and final glucose content in the incubated medium. The glucose content of the incubated medium was measured by colorimeter using GOD- POD method.

$\begin{array}{llll}\text { Sample } & \text { Consume } & \begin{array}{l}\text { Subtraction from the } \\ \text { PRO }\end{array} & \text { Percent\% } \\ \text { PRO } & 960 & & \\ \text { Control } & 930 & 30 & 3.1 \% \\ \text { Insulin } & 870 & 90 & 9.3 \% \\ \text { Extract } & 819 & 141 & 14.7 \% \\ \text { Mixture } & 294 & 666 & 69.4 \%\end{array}$

\section{4- Discussion}

This is the first study on the anti-diabetic effect of ethanolic extract of Acacia Seyal bark in induced diabetics' rats caused by injection of glucose $2 \mathrm{~g} \backslash \mathrm{kg}$. The experimental rats weighting $(80-120 \mathrm{~g})$ were used in this study. The rats were divided in to five groups, each group contain 6 rats. Group 1 was treated with $10 \mathrm{mg} \backslash \mathrm{kg}$ of glibenclamide, group 2 left as control treated with distilled water $10 \mathrm{mg} \backslash \mathrm{kg}$. Group 3 was treated with $200 \mathrm{mg}$ of ethanolic extract of Acacia Seyal bark. Group 4 was treated with 400mg of plant extract. Group 5 was treated with $800 \mathrm{mg}$ of plant extract. The standard group, the group which treated with glibenclamide cause hypoglycemia reduced the blood glucose level of diabetic rats to (140.3-139.7) at the time interval 2,4h respectively. In the group which treated with plant extract at dose $800 \mathrm{mglkg}$ reduced blood glucose level of diabetic rats to 81.3-96.3 at the time interval 2,4h respectively. In comparison with the group which treated the plant extract at dose $400 \mathrm{mg} \backslash \mathrm{kg}$ showed mordent decrease in the blood glucose level of diabetic rats to 96-123at the time interval 2,4h respectively. the group which treated the plant extract at dose $200 \mathrm{mg} / \mathrm{kg}$ given least in blood glucose level of diabetic rats to 100.2-114 at the time interval 2,4h respectively, this compatible with the other studies which used extract from different species of Acacia; Acacia farnesiana (L.) willd water extract at a dose of $50 \mathrm{mg} / \mathrm{kg}$ showed significant glucose lowering activity at 30 and 90 min after glucose loading in normal 
fed rats $\underline{24}$. Study by Rahmatullah $\mathrm{M}^{\left[25^{]}\right.}$which used Acacia catechu prepared from boiling the wood in water the different doses of extract was administered. The study concludes significant oral hypoglycemic activity on glucose-loaded mice at all doses of the extracts tested but shown less effect than that of a standard drug, glibenclamide (10 $\mathrm{mg} / \mathrm{kg}$ body weight). Another study used mixture of hops rho iso-alpha acids-rich extract and acacia proanthocy-anidins-rich extract prove that Mice fed by the mixture extract $(100 \mathrm{mg} / \mathrm{kg})$ for 7 days decrease in non-fasting glucose $22 \%$. and $19 \%$ decrease in insulin that was comparable to $0.5 \mathrm{mg} / \mathrm{kg}$ rosiglitazone and better than $100 \mathrm{mg} / \mathrm{kg}$ metformin $\underline{26}$.

To estimate how the Glucose consumed from the media in vitro by isolating diaphragm from albino rats. Each diaphragms were divided into2 halves and placed in incubating tubes. Four sets containing of incubating tubes were prepared as followed; Tube I which called PRO contained of $2 \mathrm{ml}$ of tyrode solution and $1 \mathrm{ml}$ of insulin $(0.25 \mathrm{IU} / \mathrm{ml})$, tube II which present the control contained of $2 \mathrm{ml}$ of tyrode solution, tube III contained of $2 \mathrm{ml}$ of tyrode solution and $1 \mathrm{ml}$ of extract, tube IV contained of $2 \mathrm{ml}$ of tyrode solution, $1 \mathrm{ml}$ of extract, and $1 \mathrm{ml}$ of Insulin. In the first tube which called (pro) the level of utilized glucose from the media is $3.1 \%$. In the second group which called (control) the level of utilized glucose from the media is $9.3 \%$. In third tube which called (extract) the level of utilized glucose from the media is $14 \%$. In fourth tube which called (mixture) the level of utilized of glucose from the media is $69.4 \%$ significantly increased glucose uptake by isolated rat diaphragm as compared to control, that agree with previous study which used Acacia farnesiana (L.) extract the isolated hemidiaphragm, glucose uptake was increased by treatment at $40 \mu \mathrm{g} / \mathrm{ml}$ of extract [24].

The phytochemical screening of ethanolic extracts indicated the presence of Saponin, Tannins Steroids, Triterpens, and Anthraquinone, While the absence of flavonoids. Tannin, or tannic acid, activates glucose transfer and prevents lipolysis ${ }^{[27}$. The results of study by Elmi, $\mathrm{A}^{[28]}$ suggest that $A$. seyal bark could be a potential source of active natural compounds like flavonoids, steroids, triterpenes, and tannins as catechin and gallocatechin-based oligomers. Gums are consist of (heteropolysaccharides) and condensed tannins (flavan-3-ol derivatives) are the most commonly reported constituents in Acacia. Pharmacological studies prove the antioxidant, analgesic, antihypertensive, antidiabetic, anti-Alzheimer, anti-microbial ${ }^{[29}, \underline{30}{ }^{1}$ and antimalarial effects of Acacia extracts. Acacia species constitutes of certain secondary metabolites 
including phenols, alkaloids, and terpenoids, some with useful biological activities, have been reported in acacias. Very few species have been investigated for their phytochemical composition and biological activities $\underline{[31}^{]}$.

In the best of our knowledge, no study has ever evaluated the hypoglycemic effects of A. seyal Bark in type II DM rats. Further scientific studies to isolate of bio-active constituents are highly recommended.

\section{In conclusion}

Study concluded that the ethanolic extract of A. seyal bark showed significant antidiabetic effect. In this study, In vitro glucose consumption by diaphragm the level of utilized glucose significantly higher in the presence of the extract.

Further, qualitative and quantitative phytochemical screening of Acacia Seyal bark to determine the active constitutes are recommended.

This results might have a great potential for translation to humans and the obtained data might set the stage for clinical trials investigating the effects of anti-diabetic effect in patients with diabetes mellitus type2. In the best of our knowledge, this is the first study that has conducted to study the anti-diabetics effect of ethanolic extract of Acacia Seyal bark in introduced diabetic rats.

\section{Competing interests}

The authors declare that they have no competing interests

\section{References}

1. Chamnan, P., et al., Incidence of type 2 diabetes using proposed HbAlc diagnostic criteria in the european prospective investigation of cancer-norfolk cohort: implications for preventive strategies. Diabetes Care, 2011. 34(4): p. 950-6.

r. Olokoba, A.B ‘.O.A. Obateru, and L.B. Olokoba, Type 2 diabetes mellitus: a review of current trends. Oman Med J, 2012. 27(4): p. 269-73.

r. $\quad$ Robertson, R.P., Antagonist: diabetes and insulin resistance--philosophy, science, and the multiplier hypothesis. J Lab Clin Med, 1995. 125(5): p. 560-4; discussion 565.

$\varepsilon \quad \quad$ Kahn, C.R., Banting Lecture. Insulin action, diabetogenes, and the cause of type II diabetes. Diabetes, 1994. 43(8): p. 1066-84.

- $\quad$ Fujioka, K., Pathophysiology of type 2 diabetes and the role of incretin hormones and beta-cell dysfunction. JAAPA, 2007. Suppl: p. 3-8.

7. Gomez-Peralta, F., et al., When does diabetes start? Early detection and intervention in type 2 diabetes mellitus. Rev Clin Esp (Barc), 2020. 220(5): p. 305-314.

$\checkmark$ V. Cox, M.E. and D. Edelman, Tests for Screening and Diagnosis of Type 2 Diabetes. Clinical Diabetes, 2009. 27(4): p. 132-138.

^. Harris, M.I., et al., Onset of NIDDM occurs at least 4-7 yr before clinical diagnosis. Diabetes Care, 1992. 15(7): p. 815-9. 
9. Modak, M., et al., Indian herbs and herbal drugs used for the treatment of diabetes. $\mathrm{J}$ Clin Biochem Nutr, 2007. 40(3): p. 163-73.

1. Dey, L., A.S. Attele, and C.S. Yuan, Alternative therapies for type 2 diabetes. Altern Med Rev, 2002. 7(1): p. 45-58.

11. Kingsley, B., et al., Anti-diabetes activity of Acacia farnesiana (L.) willd in alloxan diabetic rats. International Journal of PharmTech Research, 2013. 5: p. 112-118.

1r. Mukundi, M., et al., Antidiabetic Effects of Aqueous Leaf Extracts of Acacia nilotica in Alloxan Induced Diabetic Mice. Journal of Diabetes \& Metabolism, 2015. 6: p. 658664.

11. Kisoi, G. Comparative Analysis of Phytoconstituents and Caffeine Levels Of Acacia Nilotica ( Subalata) And Coffea Arabica Varieties. 2016.

1 $\varepsilon$. Singh, R. and R. Thakur, Phytochemical analysis and antibacterial activity of Acacia nilotica (L.) leaves against pathogenic bacteria. International Journal of Green Pharmacy, 2016. 10: p. 104-110.

10. Mohammed, M., Management of Natural Stands of Acacia seyal Del. variety seyal (Brenan) for Production of Gum Talha, South Kordofan, Sudan. 2011.

17. Salih, N., Applications of Gum Arabic in Medical and Health Benefits. 2018. p. 269281 .

Iv. Ahmed, A., Health Benefits of Gum Arabic and Medical Use. 2018. p. 183-210.

1^. Handa, S.S., et al., Extraction Technologies for Medicinal and Aromatic Plants. 2008: United Nation Industrial Development Organization and the International Center for Science and High Technology. 266.

19. Wall, M.E., et al., Detection and Estimation of Steroidal Sapogenins in Plant Tissue. Analytical Chemistry, 1952. 24(8): p. 1337-1341.

r. A, M. and V. G, Marchafitoquimica. In: Manual de prácticas de Farmacognosia y Fitoquímica . ed. s. edition. 2008, Colombia, South America.: Universidad de Antioquia.

r). Sofowora, A., Medicinal Plants and Traditional Medicine in Africa. 1993: Spectrum Books.

rr. Harborne., J.B., Phytochemical Methods: A Guide to Modern Techniques of Plant Analysis, ed. e. edition. 1984, London: Chapman and Hall.

rr. Parasuraman, S., R. Raveendran, and R. Kesavan, Blood sample collection in small laboratory animals. J Pharmacol Pharmacother, 2010. 1(2): p. 87-93.

rะ. Kingsley, B., et al., Pharmacodynamic studies on the isolated active fraction of Acacia farnesiana (L.) willd. Pharmacogn Mag, 2014. 10(Suppl 2) :p. S283-7.

ro. $\quad$ Rahmatullah, M., et al., Antihyperglycemic and antinociceptive activity evaluation of 'khoyer' prepared from boiling the wood of Acacia catechu in water. Afr $\mathrm{J}$ Tradit Complement Altern Med, 2013. 10(4): p. 1-5.

rч. Tripp, M.L., et al., Optimized mixture of hops rho iso-alpha acids-rich extract and acacia proanthocyanidins-rich extract reduces insulin resistance in 3T3-L1 adipocytes and improves glucose and insulin control in db/db mice. Nutr Res Pract, 2012. 6(5): p. 405-13.

rv. Sawant, R s.et al., Phytochemical analysis of bark of Acacia nilotica. Asian Journal of Plant Science and Research, 2014. 2014: p. 22-24.

r^. Elmi, A., et al., Evaluation of Antioxidant and Antibacterial Activities, Cytotoxicity of Acacia seyal Del Bark Extracts and Isolated Compounds. Molecules, 2020. 25.

५१. Aryal, B., et al., Antidiabetic, Antimicrobial, and Molecular Profiling of Selected Medicinal Plants. Evid Based Complement Alternat Med, 2021. 2021: p. 5510099.

r. M.F. Moustafa, and E. Eid ، Genetic variability, antimicrobial activity and natural water-soluble vitamins contents of five acacia species growing in Jazan Region, Saudi Arabia. Pakistan Journal of Agricultural Sciences, 2019. 56: p. 289-300.

1). Subhan, N., et al., Phytochemistry 'Ethnomedicine, and Pharmacology of Acacia. 2018. p. 247-326. 